\title{
Correlation and Path Analysis Studies of Quality Parameters in Rice Genotypes
}

\author{
M. Shivakumar*, K. Radhika, N. Sarla and V. Venkanna \\ ${ }^{1}$ Department of Genetics and Plant Breeding, College of Agriculture, Rajendranagar, \\ PJTSAU, Hyderabad-500030, India \\ ${ }^{2}$ Indian Institute of Rice Research, Rajendranagar, Hyderabad-500030, 3Regional \\ Agricultural Research Station, Warangal-506 007, India
}

*Corresponding author

A B S T R A C T

\begin{tabular}{|l|}
\hline Ke y w or d s \\
Rice, Yield, Quality \\
parameters, \\
Correlation, Path \\
analysis
\end{tabular}

Development of micronutrient enriched staple foods is an important breeding goal in view of the extensive problem of 'hidden hunger' caused by micronutrient malnutrition. Iron and zinc are micronutrients essential to the human diet but are in deficient supply to many to many in the Tropics. In an effort to this problem through genetic improvement, field trials of Rice (60 Genotypes) were conducted at Jagtial during kharif 2014 to study the Association and path analysis. No significant correlation was reported between seed yield / plant and its quality parameters including grain dimensions and nutrient traits both at phenotypically and genotypically. These suggested that, there is possibility of selection for these traits without detrimental effect on seed yield/plant. The estimates of direct and indirect effect revealed that L/B ratio had the highest positive direct effect on seed yield / plant followed by Kernel breadth and kernel length and negatively with Grain iron and zinc concentrations.

\section{Introduction}

Rice is an extensively grown important staple food crop, accounting for $43 \%$ of the total food grain production of the country. The economic product of rice, exhibits complex genetics and is influenced by various yield contributing characters. Along with yield, grain and nutritional quality has also become a primary consideration in rice breeding. Iron and Zinc deficiency is probably the most widespread micronutrient deficiencies in cereals. A lot of efforts are being made to enrich the nutritional status of rice to prevent malnutrition. Better understanding of the contribution of component traits in building the genetic make-up of the crop can be obtained through correlation studies. Correlation coefficient does not provide exact picture of relative importance of direct and indirect influence of each component character. Wright (1921) devised the analysis 
of path coefficient to provide an effective means of finding out direct and indirect causes of association (Garg et al., 2010).

\section{Materials and Methods}

The experimental material comprised of 60 strains including 42 rice varieties and 18 rice genotypes. The experiment was conducted in randomised block designed (RBD) with three replications. Thirty days old seedlings were transplanted at a spacing of $20 \times 15 \mathrm{~cm}$ and recommended package of practices were followed. Planting was done with one healthy seedling per hill. Ten competitive plants from each hybrid in each replication were selected at random to record the data. The quality and yield characters were estimated by standard procedures reported like Kernel length, Kernel breadth, Kernel L/B ratio using Dialmicrometer and Grain iron and zinc concentrations were determined by X-Ray fluorescence Spectrometry and Seed yield / plant. Statistical analysis for the above five characters were done following Falconer (1981) for correlation and Wright (1921) and Dewey and $\mathrm{Lu}$ (1959) for path analysis.

\section{Results and Discussion}

The analysis of variance revealed significant differences among the genotypes for all the characters studied. Knowledge on association will help in selection of characters during breeding programme. The genotypic correlation coefficients were of higher magnitude than the corresponding phenotypic correlation coefficients for most of the character pairs, indicating a strong inherent association between these characters (Table $1)$.

Seed yield/plant showed positive correlation with Kernel length, Kernel L/B ratio, while negative correlation with Kernel breadth, Grain iron and zinc concentrations. This indicated that all these characters are important for yield improvement. These results are in conformity with earlier reports of Sabesan et al., (2009) for kernel length, Mohanty et al., (2012) for Kernel L/B ratio. Kernel length showed positive and significant association with Kernel breadth and kernel $\mathrm{L} / \mathrm{B}$ ratio, which is in agreement with the findings of Mohanty et al., (2012) and Umarani (2014) for kernel L/B ratio. Kernel breadth had negative and significant association with kernel L/B ratio. Mohanty et al., (2012) also obtained similar reports. Positive and significant association between grain iron and zinc concentrations corroborates the results of Umarani (2014). This may indicate that direct selection of grain iron concentration would likely be effective in increasing the grain zinc concentration.

Path coefficient analysis at phenotypic and genotypic levels was worked out to know the cause and effect of relationship between the yield and quality contributing characters (Table 2). It revealed that kernel L/B ratio was the most important character because of its higher positive direct effect followed by kernel breadth both at phenotypic and genotypic levels and kernel length at phenotypic level. These results are in unison with the findings of Aditya and Bhartiya (2013) for kernel L/ B ratio and kernel breadth and Umarani (2014) for kernel length. Negative direct effect was found in grain iron and zinc concentrations both at phenotypic and genotypic levels and kernel length at genotypic level. Nagesh (2011) and Umarani (2014) observed similar results for grain iron concentration and Subudhi et al., (2011) for kernel length characters in rice.

The genetic architecture of grain yield and quality is based on the balance or overall net produced by various their component traits interacting with one another. Hence these characters need to be considered while designing a selection strategy for yield improvement and quality enhancement in rice. 
Table.1 Phenotypic and genotypic correlation coefficients between yield and grain quality parameters for Jagtial location

\begin{tabular}{|c|c|c|c|c|c|c|c|}
\hline Character & & $\begin{array}{l}\text { Kernel length } \\
\quad(\mathrm{mm})\end{array}$ & $\begin{array}{c}\text { Kernel } \\
\text { breadth }(\mathrm{mm})\end{array}$ & $\begin{array}{l}\text { Kernel L/B } \\
\text { ratio }\end{array}$ & $\begin{array}{c}\text { Grain iron } \\
\text { concentration } \\
(\mathrm{ppm})\end{array}$ & $\begin{array}{c}\text { Grain zinc } \\
\text { concentration } \\
(\mathrm{ppm})\end{array}$ & $\begin{array}{l}\text { Seed yield / } \\
\text { plant }(\mathrm{g})\end{array}$ \\
\hline \multirow[t]{2}{*}{ Kernel length (mm) } & $\mathbf{P}$ & 1.0000 & $0.3828 * *$ & $0.6492 * *$ & 0.1081 & -0.0338 & 0.0748 \\
\hline & $\mathbf{J}$ & 1.0000 & $0.3959 * *$ & $0.6388 * *$ & 0.1104 & -0.0335 & 0.0817 \\
\hline \multirow[t]{2}{*}{ Kernel breadth (mm) } & $\mathbf{P}$ & & 1.0000 & $-0.4470 * *$ & 0.0841 & 0.1425 & -0.0566 \\
\hline & $\mathbf{J}$ & & 1.0000 & $-0.4464 * *$ & 0.0878 & 0.1415 & -0.0664 \\
\hline \multirow[t]{2}{*}{ Kernel L/B ratio } & $\mathbf{P}$ & & & 1.0000 & 0.0391 & -0.1283 & 0.1181 \\
\hline & $\mathbf{J}$ & & & 1.0000 & 0.0385 & -0.1290 & 0.1362 \\
\hline \multirow{2}{*}{$\begin{array}{l}\text { Grain iron } \\
\text { concentration (ppm) }\end{array}$} & $\mathbf{P}$ & & & & 1.0000 & $0.5583 * *$ & -0.0849 \\
\hline & $\mathbf{J}$ & & & & 1.0000 & $0.5635 * *$ & -0.0887 \\
\hline \multirow{2}{*}{$\begin{array}{l}\text { Grain zinc } \\
\text { concentration (ppm) }\end{array}$} & $\mathbf{P}$ & & & & & 1.0000 & -0.0976 \\
\hline & $\mathbf{J}$ & & & & & 1.0000 & -0.1080 \\
\hline
\end{tabular}

Table.2 Phenotypic and genotypic path coefficients between yield and grain quality parameters for Jagtial location

\begin{tabular}{|l|c|c|c|c|c|c|c|}
\hline Character & & $\begin{array}{c}\text { Kernel } \\
\text { length }(\mathrm{mm})\end{array}$ & $\begin{array}{c}\text { Kernel } \\
\text { breadth }(\mathrm{mm})\end{array}$ & $\begin{array}{c}\text { Kernel L/B } \\
\text { ratio }\end{array}$ & $\begin{array}{c}\text { Grain iron } \\
\text { concentration } \\
(\mathrm{ppm})\end{array}$ & $\begin{array}{c}\text { Grain zinc } \\
\text { concentration } \\
(\mathrm{ppm})\end{array}$ & $\begin{array}{c}\text { Seed yield / } \\
\text { plant }(\mathrm{g})\end{array}$ \\
\hline Kernel length $(\mathrm{mm})$ & $\mathbf{P}$ & $\mathbf{0 . 0 0 2 5}$ & 0.0024 & 0.0750 & -0.0068 & 0.0016 \\
\hline & $\mathbf{G}$ & $\mathbf{- 0 . 1 6 4 8}$ & 0.0584 & 0.1927 & -0.0067 & 0.0021 & 0.0748 \\
\hline Kernel breadth & $\mathbf{P}$ & 0.0010 & $\mathbf{0 . 0 0 6 3}$ & -0.0517 & -0.0053 & -0.0069 & -0.0566 \\
\hline (mm) & $\mathbf{G}$ & -0.0653 & $\mathbf{0 . 1 4 7 5}$ & -0.1347 & -0.0053 & -0.0087 & -0.0664 \\
\hline Kernel L/B ratio & $\mathbf{P}$ & 0.0016 & -0.0028 & $\mathbf{0 . 1 1 5 6}$ & -0.0025 & 0.0062 & 0.1181 \\
\hline Grain iron & $\mathbf{G}$ & -0.1053 & -0.0659 & $\mathbf{0 . 3 0 1 7}$ & -0.0023 & 0.0079 & 0.1362 \\
\hline concentration $(\mathrm{ppm})$ & $\mathbf{P}$ & 0.0003 & 0.0005 & 0.0045 & $\mathbf{- 0 . 0 6 3 3}$ & -0.0269 & -0.0849 \\
\hline $\begin{array}{l}\text { Grain zinc } \\
\text { concentration }(\mathrm{ppm})\end{array}$ & $\mathbf{G}$ & -0.0182 & 0.0130 & 0.0116 & $\mathbf{- 0 . 0 6 0 5}$ & -0.0346 & -0.0887 \\
\hline
\end{tabular}




\section{References}

Aditya J.P and Bhartiya, A. 2013. Genetic variability, correlation and path analysis for quantitative characters in rainfed upland rice of Uttarakhand hills. Journal of Rice Research. 6(2): 24-34.

Dewey, J.R and Lu, K.H. 1959. Correlation and path coefficient analysis of components of crested wheat grass seed production. Agronomy Journal. 51: 515-518.

Falconer D.S. 1981. Introduction to Quantitative Genetics. $2^{\text {nd }}$ Edition. Longman, New York.

Garg, P., Pandey, D.P and Dhirendrasingh. 2010. Correlation and path analysis for yield and its components in rice (Oryza sativa L.). Crop Improvement. 37 (1): 46-51

Mohanty, N., Sekhar, M.R., Reddy, D.M and Sudhakar, P. 2012. Genetic variability and character association of agromorphological and quality characters in rice. Oryza. 49 (2): 88-92.
Nagesh. 2011. Studies on combining ability analysis for high iron and zinc, identifying the regions associated with iron and zinc content in rice (Oryza sativa L.) grains. Ph.D. Thesis. Acharya N.G. Ranga Agricultural University, Hyderabad.

Sabesan, T., Suresh, R and Saravanan, K. 2009. Genetic variability and correlation for yield and grain quality characters of rice grown in coastal saline low land of Tamilnadu. Electronic Journal of Plant Breeding. 1: 56-59.

Subudhi, H.N., Das, S., Swain, D and Singh, O.N. 2011. Variability, correlation and path analysis for quality characters in rice. Oryza. 48(4): 319-323.

Umarani, E. 2014. Evaluation of land races of rice (Oryza sativa L.) for genetic diversity. M.Sc (Ag) thesis. Acharya N.G. Ranga Agricultural University, Hyderabad.

Wright, S. 1921. Correlation and causation. Journal of Agriculture Research. 20: 557-58.

\section{How to cite this article:}

Shivakumar, M., K. Radhika, N. Sarla and Venkanna, V. 2018. Correlation and Path Analysis Studies of Quality Parameters in Rice Genotypes. Int.J.Curr.Microbiol.App.Sci. 7(07): 132135. doi: https://doi.org/10.20546/ijcmas.2018.707.016 